\title{
MORALISMO POLÍTICO E RESTRIÇÕES A DIREITOS FUNDAMENTAIS*
}

\author{
ORIDES MEZZAROBA** \\ CARLOS LUIZ STRAPAZZON ${ }^{* * *}$
}

\begin{abstract}
RESUMO: O Brasil aprovou uma lei eleitoral conhecida como Lei da ficha limpa (LC 135, de 4.06.2010). A referida Lei estabelece casos de inelegibilidade que visam proteger a probidade administrativa e a moralidade no exercício do mandato eletivo. Essa Lei restringe direitos cívicos fundamentais de cidadãos ainda não condenados definitivamente pelo Poder Judiciário, entrou em vigor antes do período mínimo exigido pelo art. 16 da Constituição, restringiu direitos políticos de cidadãos a partir de 2 anos antes de sua entrada em vigor. Há, como se vê, graves antinomias entre as regras dessa lei e os princípios e regras constitucionais vigentes no Brasil. Este texto analisa por que a interpretação constitucional deve assegurar a máxima eficácia dos direitos fundamentais e também por que a nova Lei viola princípios constitucionais rigidamente protegidos, quer pelo texto constitucional, quer pela jurisprudência do STF.
\end{abstract}

PALAVRAS-CHAVE: Direitos Fundamentais; Direitos Políticos; Constituição; Garantismo; Lei das Inelegibilidades.

ABSTRACT: Brazil approved an electoral law known as clean sheet Act (LC 135, 04.06.2010). This Act establishes ineligibility cases designed to protect administrative probity and morality in the exercise of elective office. It restricts basic civil rights of citizens not yet definitively condemned by the judiciary, it has entered into force before the minimum period required by art. 16 of the Constitution, and it limited political rights of citizens from two years before its entry into force. There is, you see, serious contradictions between its rules and principles and brazilian Constitution. This article explains why constitutional interpretation should ensure maximum effectiveness of fundamental rights, also explains why this new act violates constitutional principles rigidly protected, either by the Constitution or by case law and the Supreme Court.

\footnotetext{
Artigo recebido em 20.01.2011. Pareceres emitidos em 21.03.2011 e 16.03.2011.

Artigo aceito para publicação em 12.04.2011.

* Este artigo é dedicado a Técio Lins e Silva pela sua inspiradora defesa das liberdades.

** Pós-Doutor em Direito (Universidade de Coimbra, Portugal). Doutor em Direito (Universidade Federal de Santa Catarina, Florianópolis). Professor dos Programas de Graduação e Pós-Graduação em Direito (Mestrado e Doutorado) da Universidade Federal de Santa Catarina, Florianópolis. Pesquisador de Produtividade do CNPq.

**** Doutorando em Direito Constitucional (Universidade Federal de Santa Catarina, Florianópolis). Professor-pesquisador em Direitos Fundamentais (Universidade do Oeste de Santa Catarina, Chapecó), Professor convidado da Escola da Associação dos Magistrados do Trabalho do Paraná, Curitiba.
} 
KEYWORDS: Fundamental Rights; Political Rights; Constitution; Guarantism; Ineligibilities Act.. SUMÁRIO: 1. O projeto ficha limpa; 2. Democracias constitucionais e
responsividade jurisdicional; 3. Garantismo e a doutrina do núcleo essencial dos
direitos fundamentais; 4 . Garantias fundamentais aplicáveis a cidadãos no pleno
exercício de suas liberdades fundamentais, a candidatos em campanha eleitoral
e a representantes eleitos; 5. Não culpabilidade: para além do direito penal
em sentido estrito; 6 . Inelegibilidade na evolução jurisprudencial do STF;
7. Hipóteses de inelegibilidades com natureza sancionatória; 8 . A lei da Ficha
limpa nas decisões recentes do TSE e STF; 9. Sentido e alcance da garantia do
Art. $5^{\circ}$, LVII da CRFB; Considerações Finais; Referências.

SUMMARY: 1. The "clean sheet" project; 2. Constitutional democracies and judicial responsiveness; 3 . Guarantism and the doctrine of the essential core of fundamental rights; 4 . Fundamental guarantees applicable to citizens in the full exercise of their freedoms to citizens in political campaigns and to elected representatives; 5 . Culpability principle: beyond the sense strict of criminal law; 6. Ineligibility jurisprudential developments in the Federal Supreme Court; 7. Hypotheses of ineligibility with a sanctioning nature; 8 . The clean sheet Act in recent decisions of the Electoral Superior Court and Federal Supreme Court; 9. Meaning and scope of the guarantee of Article 5., LVII of the Brazilian Constitutuion; Concluding Remarks; References.

\section{O PROJETO FICHA LIMPA}

No Brasil, felizmente, tudo conspira em favor do amadurecimento do regime político criado em 1988. Uma consequência disso é a progressiva consolidação da democracia, a melhor compreensão do sistema eleitoral e a simplificação do sistema partidário, sobretudo para eleições majoritárias (LIMONGI; CORTEZ, 2010, p. 36). Afinal, que regime é esse que está se consolidando no Brasil? O que pode ser constatado é o aprimoramento de políticas públicas que vêm transformando a democracia eleitoral em uma democracia que prioriza a cidadania, que se legitima de forma intensa tomando como pressupostos os direitos fundamentais (entendidos como: liberdades individuais, direitos civis, direitos políticos, direitos sociais e direitos coletivos). Diante disso, pode-se afirmar que vigora, no Brasil, um sistema político e jurídico comprometido com os valores básicos de cidadania em sentido amplo. Um sistema profundamente enraizado em ideais de liberdade, inclusão econômica e social, bem como em práticas governamentais que estimulem a participação popular. Estas características conferem à democracia brasileira qualidades de regime liberal, plural, competitivo, tolerante e inclusivo. Os sinais vitais de qualquer democracia se fortalecem assim que essas qualidades jurídicas são eficazes e na medida em que os indivíduos e grupos organizados participam livremente dos processos decisórios que os afetam. No entanto, rotinas eleitorais normais e mesmo a satisfação dos interesses das maiorias podem não traduzir, com precisão, o tipo de democracia que é o Brasil: uma democracia constitucional.

O sentido mais elaborado de uma democracia constitucional será apresentado ao longo deste trabalho; por enquanto, basta dizer que se trata 
de um tipo de regime político aberto que, como todos os seus semelhantes, dá condições para a crítica das práticas e das instituições existentes, abrindo possibilidades para o surgimento de outras novas, isto é, a mudança e a inovação nas expectativas estabelecidas é um traço típico desses regimes.

Em 29 de setembro de 2009, por exemplo, o Movimento de Combate à Corrupção Eleitoral (MCCE), no exercício de suas liberdades democráticas, propôs a mudança da Lei Complementar 64/1990, a Lei brasileira que define as causas de inelegibilidade. O projeto de lei popular levou o apelido de Projeto ficha limpa ${ }^{1}$. No site do MCCE (www.mcce.org.br) foram expostas as razões que o justificavam (PLP 518):

Se a Constituição prevê a consideração da vida pregressa como fator capaz de gerar uma inelegibilidade, por que isso não foi observado até agora? Resposta: Por que falta ao Congresso Nacional editar a lei complementar exigida pelo $\S 9^{\circ}$ do art. 14 da CF. Por que o projeto de lei não ofende o princípio constitucional da presunção de inocência? Resposta: É que o princípio da não culpabilidade ou da presunção de inocência se aplica apenas ao âmbito penal. No âmbito eleitoral, prevalecem outros princípios constitucionais! Como o principio da "precaução".

A proposta original $^{2}$ do MCCE visava regulamentar o princípio constitucional da precaução eleitoral, instituído no art. 14 da CRFB, em 1994, pelo novo $\S 9^{0^{3}}$, e tornar inelegíveis os cidadãos condenados em primeiro grau, ou os

\footnotetext{
${ }^{1} \mathrm{O}$ autor do Projeto foi o Dep. Antonio Carlos Biscaia (PT-RJ). Os coautores da primeira versão do projeto foram: Arnaldo Jardim - PPS/SP; Camilo Cola - PMDB/ES; Carlos Sampaio - PSDB/SP; Celso Maldaner - PMDB/SC; Chico Alencar - PSOL/RJ; Domingos Dutra - PT/MA; Dr. Rosinha PT/PR; Duarte Nogueira - PSDB/SP; Fátima Bezerra - PT/RN; Felipe Maia - DEM/RN; Fernando Chiarelli - PDT/SP; Fernando Coruja - PPS/SC; Fernando Ferro - PT/PE; Hugo Leal - PSC/RJ; Humberto Souto - PPS/MG; Ivan Valente - PSOL/SP; João Moraes - PCdoB/MG; Luiz Carlos Hauly PSDB/PR; Luiz Couto - PT/PB; Manato - PDT/ES; Marcelo Ortiz - PVISP; Mendonça Prado DEM/SE; Miro Teixeira - PDT/RJ; Odair Cunha - PT/MG; Osmar Serraglio - PMDB/PR; Paulo Rubem Santiago - PDT/PE; Rafael Guerra - PSDB/MG; Rita Camata - PMDB/ES; Rodovalho DEM/DF; Vieira da Cunha - PDT/RS; Washington Luiz - PT/MA; Zenaldo Coutinho - PSDB/PA.

${ }^{2}$ A proposta mais antiga, que alterava a Lei de Inelegibilidades (LC 64/90), foi o Projeto de Lei Complementar 168/1993, encaminhada pelo Poder Executivo. Apensados a ele, existiam outras 13 (treze) propostas. Em 16 de março de 2010, realizou-se a última audiência pública do Grupo de Trabalho da Câmara dos Deputados.

${ }^{3} \mathrm{O}$ atual parágrafo nono do art. 14 da CRFB, não é original. Foi criado por emenda durante os trabalhos da mal sucedida Revisão Constitucional de 1994. A Revisão foi realizada numa época de crise política: o Congresso, depois da CPI do PC Farias, havia enfrentado a CPI do Orçamento, que levou à cassação de seis parlamentares e à renúncia de outros tantos. Um ano antes, os brasileiros haviam manifestado, em plebiscito, que não queriam mudar a forma e o sistema de governo, mantendo a República presidencialista. A revisão seria decisiva caso o plebiscito resultasse numa escolha pelo regime parlamentarista. Além disso, os brasileiros estavam atentos às primeiras medidas do Plano Real. Ainda, no ano de 1994 haveria eleições e por razões eleitorais, tanto deputados quanto senadores, não queriam mexer na "Constituição cidadã". Outro motivo é que nos seus primeiros anos, a Constituição foi muito criticada por empresários, sob o argumento de que ela apresentava direitos em excesso e poucos deveres para os trabalhadores e cidadãos. Os parlamentares oposicionistas temiam a reorganização do grupo político conhecido na imprensa
} 
que tivessem contra si denúncia recebida por órgão judicial colegiado ou que tivessem sido condenados em qualquer instância por ato de improbidade administrativa, desde a condenação ou do recebimento da denúncia. Em meados de março de 2010, o substitutivo (Emenda de Plenário n. 21) do deputado federal Índio da Costa (DEM-RJ), suprimiu a referida a inelegibilidade por condenação por juiz singular. Previu, em vez, que a inelegibilidade dos candidatos valeria somente após a condenação em órgão colegiado, independentemente da instância. Em 20 de abril de 2010, a Comissão de Constituição e Justiça e de Cidadania da Câmara Federal (CCJ) incluiu no texto a possibilidade de políticos condenados em segunda instância, por decisão colegiada, registrarem suas candidaturas se o Superior Tribunal de Justiça provesse recurso suspensivo da condenação.

É visível que, de setembro de 2009, quando foi apresentada a versão original do PLP n. 518, até a versão final, as emendas apresentadas ao parecer do relator do Grupo de Trabalho, Dep. Índio da Costa (DEM-RJ), mudaram-Ihe a perspectiva constitucional. O PLP original, fundado - como era de esperar - no clamor público, fez vistas grossas aos direitos subjetivos dos acusados em geral. A versão mais recente revelou um importante esforço para criar garantias contra a censura prévia e respeitar a garantia da presunção de não culpabilidade ${ }^{4}$, de que o PLP fora acusado (STRAPAZZON 2010).

por "Centrão", o qual poderia impor retrocessos aos avanços sociais obtidos cinco anos antes. Por conta dessas razões, as seis emendas de Revisão foram aprovadas sem maiores polêmicas: A emenda 1 criou o Fundo Social de Emergência, permitindo ao governo dispor com autonomia de parte da arrecadação para o saneamento financeiro da União. A emenda 2 alterou a redação do Art. 50, sobre os poderes de convocação de Ministros, a ser exercido pelo Congresso Nacional. A emenda 3 alterou características de nacionalidade brasileira, na alínea "c" do inciso I, na alínea "b" do inciso II, no $\S 1^{\circ}$ e no inciso II do $\S 4^{\circ}$ do art. 12 da Constituição Federal. A emenda 4 é a emenda da "vida pregressa": alterou o $\S 9 .^{\circ}$ do art. 14 da Constituição para acrescentar as expressões: a probidade administrativa, a moralidade para o exercício do mandato, considerada a vida pregressa do candidato. A redação original era: Art. $14 \S 9^{\circ}$. Lei complementar estabelecerá outros casos de inelegibilidade e os prazos de sua cessação, a fim de proteger a probidade administrativa, a moralidade para o exercício do mandato, considerada a vida pregressa do candidato, e a normalidade e legitimidade das eleições contra a influência do poder econômico ou o abuso do exercício de função, cargo ou emprego na administração direta ou indireta. A emenda n. 5 reduziu o mandato do presidente da República de cinco para quatro anos. A emenda n. 6 suspendeu os efeitos da renúncia de parlamentar submetido a processo de perda de mandato.

${ }^{4}$ Foi a Constituição da Itália que produziu essa expressão "presunção de não culpabilidade". $\mathrm{Na}$ fase dos trabalhos constituintes, a doutrina italiana se debateu muito na busca da segurança dogmática e da diferença específica entre "não culpabilidade" e "inocência". A razão predominante para a utilização dessa fórmula reside no cuidado de não repetir a linguagem do processo penal do século XVIII. A expressão "não culpabilidade" atenua a ênfase da expressão "inocência". É, segundo Tupini, o Presidente da Subcomissão encarregada da redação da norma, uma fórmula que propõe uma dosagem mais prudente da garantia, sem apelos românticos. Presumir a não culpabilidade é aplicar o benefício da dúvida ao acusado durante todo o processo, que, por criar uma possibilidade de privá-lo de um direito fundamental, deve ser regido pelos princípios do due process até que se obtenha decisão definitiva que pode, esta sim, aplicar uma privação ou restrição de direito fundamental ao acusado (culpa em sentido jurídico). Essa leitura garantista significa que o fato simples da imputação não tem o condão de produzir uma alteração no status do imputado. Ele permanece não intocado até a decisão definitiva. O processo penal do regime fascista fora 
A nova versão sugeriu fórmulas recursais inovadoras e trouxe um mínimo de due process of law. A nova rodada de discussões na Câmara dos Deputados gerou alguns consensos: o político se tornaria inelegível só após ser condenado em órgão colegiado, no entanto, por um período de oito anos.

O projeto original da ficha limpa foi assinado por 1.516 .479 cidadãos. Esse movimento nacional pela higienização moral da política se posicionou contra a registrabilidade de políticos envolvidos em corrupções. Ao que tudo indica, estava muito bem articulado enquanto grupo de pressão popular em busca de afirmação de suas legítimas expectativas. Mais difícil, porém, é harmonizar essas expectativas populares com direitos políticos constitucionais que garantem a presunção de não culpabilidade, a anualidade eleitoral e a não retroatividade punitiva. Efetivar essa harmonização é a razão de ser das democracias constitucionais. Não se pode, todavia, esperar isso de um grupo de pressão, como o MCCE. É legítimo, e exigível, que o Poder Legislativo e o Poder Judiciário façam esse trabalho.

O que realmente ocorreu nas deliberações parlamentares e nas decisões judiciais será discutido, criticamente, a partir de agora.

Na brevíssima exposição de motivos constante do relatório do Deputado Índio da Costa (DEM-RJ), afirma ele, com notável descuido técnico, que o intuito do substitutivo seria o de impedir que indivíduos de conduta duvidosa viessem a representar o povo brasileiro. $O$ direito individual ao benefício da dúvida seria relativizado para, em seu lugar, prevalecer a presunção de culpabilidade em matéria eleitoral, tudo em nome do dever geral de precaução.

Em qualquer democracia constitucional a moral, a política e o direito se influenciam mutuamente, de modo que um é o limite da atuação do outro. Por isso, até mesmo a vontade popular de mudar as leis, sobretudo as que instituem privação de bens ou restrição a direitos, têm limites graves. É lição antiga que o Constitucionalismo liberal corresponde à idéia de que o governo é limitado, ou que pode ter seus poderes limitados; que sua autoridade depende de uma criteriosa observação de limites:

[...] a Constituição republicana, se a quiséssemos reduzir a uma só palavra, concentrá-la em uma só instituição, diríamos [...] é essa instituição criada, sobretudo para servir de dique, de barreira e de freio às maiorias parlamentares, para conter as expansões do espírito do partido [...] O Supremo Tribunal é essa força, criada, sobretudo para

qualificado como inquisitório (o ônus de provar a inocência era do acusado), policialesco (prisões preventivas durante a fase investigativa) e burocrático (tratar pessoas como números). A fórmula adotada na Constituição da Itália é uma resposta a um passado autoritário e teve o juiz penal como seu principal destinatário. A nova redação da Constituição italiana desejou, em primeiro lugar, circunscrever o instituto da prisão preventiva a situações graves, emergenciais e não violadoras da dignidade da pessoa humana; em segundo lugar, suprimir todas as presunções que deveriam ser desconstituídas pelo acusado no sistema probatório. Essas posições foram claramente referendadas pela Corte Constitucional nas Sentenças n. 1 de 1980 e n. 48 de 1994 e amparam os imputados tanto na fase investigativa quanto na fase probatória (BATIA; PIZZO; 2005) 
isso, tendo essencialmente por fim isso; - dizer ao Poder Legislativo: até aqui permite a Constituição que vás; daqui não permite a Constituição que passes. (BARBOSA, 1915, p. 19)

Uma democracia constitucional, no entanto, exige ponderação entre as formas de proteger a moralidade administrativa e as formas de proteger as liberdades individuais. Nenhum princípio pode anular o outro. Nenhum pode, igualmente, deixar de ter efeitos.

É por isso que as causas de inelegibilidade instituídas para dar eficácia ao princípio da precaução contra atos que podem macular a moralidade administrativa precisam justificar corretamente sua eventual precedência em face das liberdades individuais ou, se não houver tal precedência, todas as causas de inelegibilidade devem ser harmônicas com garantias de liberdades, como a presunção de não culpabilidade e com liberdades cívicas fundamentais, como as liberdades gerais de ação política.

\section{DEMOCRACIAS CONSTITUCIONAIS E RESPONSIVIDADE JURISDICIONAL}

As democracias constitucionais estão assentadas em postulados responsivos. No campo jurídico das democracias constitucionais, é bem conhecida a evolução para um constitucionalismo rígido que adota uma ampliada noção de direitos fundamentais. A busca da máxima efetividade dos direitos fundamentais fez surgir, de um lado, um postulado hermenêutico que a doutrina jurídica portuguesa denomina de adequação formal (Art. 265-a CPC Portugal), que é em tudo coerente com os postulados garantistas, surgidos na Itália. Ambos são plenamente coerentes com as exigências políticas das democracias responsivas, pois refletem a intolerância da cidadania com procedimentalismos excessivos, com a omissão administrativa e com técnicas de interpretação que minimizem a eficácia de direitos constitucionais fundamentais. Em síntese, rejeitam-se todas as práticas que retardam as respostas efetivas do Estado (políticas ou jurisdicionais) em matéria de efetividade dos direitos humanos.

Os procedimentos legais que, de um lado, conferem validade às decisões, de outro precisam se adaptar aos conteúdos e necessidades de efetiva proteção das liberdades e concretização dos direitos constitucionais. É por isso que as democracias constitucionais sujeitaram todo o aparato estatal a novas expectativas jurídicas que se expressam pela exigência de respostas e decisões coerentes com os direitos fundamentais.

Esse esquema constitucional novo conduziu Ferrajoli (2007, p. 316), por exemplo, a incluir, na sua teoria garantista do direito, o princípio da estrita legitimidade, como complemento do princípio da estrita legalidade, que é princípio apenas formal de validade dos atos jurídicos. Nas democracias responsivas, as expectativas constitucionais em relação a direitos fundamentais têm o condão de vedar omissões; convertem-se em direitos fundamentais a algum tipo de prestação positiva, seja do estado, seja da sociedade. 
Guardiãs dos preceitos constitucionais fundamentais, as Cortes Constitucionais são as instituições de garantia desse projeto civilizatório centrado nos direitos humanos, nova moralidade jurídica que não admite retrocessos em matéria de direitos fundamentais.

Essa linha de entendimento está muito bem respaldada no Supremo Tribunal Federal:

Os magistrados e Tribunais, no exercício de sua atividade interpretativa, especialmente no âmbito dos tratados internacionais de direitos humanos, devem observar um princípio hermenêutico básico (tal como aquele proclamado no Artigo 29 da Convenção Americana de Direitos Humanos), consistente em atribuir primazia à norma que se revele mais favorável à pessoa humana, em ordem a dispensar-lhe a mais ampla proteção jurídica. (HC 98.893 MC/SP. Relator: Min. Celso de Mello. 09.06.2009)

Essa afirmação de uma hermenêutica que se orienta pela maximização da eficácia dos direitos fundamentais também reconhece, nos procedimentos e técnicas interpretativas, primazia às liberdades fundamentais, aos direitos de igualdade e aos direitos coletivos, porque foram alçados à condição de núcleo axiológico da ideologia constitucional contemporânea.

3. GARANTISMO E A DOUTRINA DO NÚCLEO ESSENCIAL DOS DIREITOS FUNDAMENTAIS

O garantismo é um corpus teórico de onde deriva uma das mais vigorosas doutrinas penais da atualidade, é também um discurso crítico do sistema punitivo vigente, em especial das reações jurídicas ao clamor popular por severidade na aplicação do direito — donde a crescente expansão das tutelas penais de urgência, multiplicação de tipos penais e, por isso, de criminalização, ou seja, tendência de o sistema punitivo expandir-se para além dos limites estabelecidos pelas normas que o regulam (FERRAJOLI, 2006, p. 701).

Para além de promover a releitura do direito constitucional em face dessas situações abusivas, está nos fundamentos do garantismo jurídico a crítica à omissão e ao insuficiente esforço hermenêutico para maximizar a concretização dos direitos constitucionais fundamentais. Por um olhar garantista, é inadequada a utilização de postulados hermenêuticos que não geram interpretações conformes aos direitos fundamentais constitucionais e que não visem à sua máxima efetividade ${ }^{5}$ em face das proteções insuficientes ou dos abusos de direito (do Estado nas relações jurídicas privadas ${ }^{6}$ ).

\footnotetext{
${ }^{5} \mathrm{O}$ jurista, ao criticar o direito vigente (e para Ferrajoli isto é fazer ciência), assume os valores constitucionalmente positivados como parâmetros do próprio discurso jurídico, independentemente da sua adesão moral. [...] O Sistema Garantista pode ser definido como uma técnica de diminuição da discricionariedade e maximização das expectativas garantidas como direitos fundamentais. Assim, as suas forças e fraquezas decorrem ambas da luta individual e coletiva pela defesa dos direitos fundamentais (CADEMARTORI; XAVIER, 2006).

${ }^{6} \mathrm{O}$ garantismo, que sempre foi elaborado no confronto dos poderes públicos, deve ser também
} 
Em sua renomada obra Direito e razão, Ferrajoli (2006, p. 355, tradução nossa) lecionou que:

[N]os modernos estados constitucionais de direito, [...] a validade das normas - seja das leis, regulamentos, sentenças ou atos normativos - reside em sua conformidade não só formal senão também substancial com normas de nível superior, que não só regulam as formas senão que ditam também limitações de conteúdo ao exercício do poder normativo. Nestes ordenamentos a validade não depende só dos aspectos formais de produção normativa [...] depende igualmente do significado dos enunciados normativos produzidos, e mais exatamente, da valoração da conformidade de seu conteúdo com o "dever ser" jurídico estabelecido pelas normas superiores.

Em trabalho mais recente Ferrajoli (2007, p. 1016) revisou toda a teoria geral do direito ocidental a partir de uma visão renovada da teoria deôntica, da teoria política, da teoria da linguagem jurídica e de uma teoria do direito positivo que seja coerente com a filosofia do atual Estado Constitucional de Direito. Retorna, então, às lições anteriores para sustentar que a essência do constitucionalismo rígido contemporâneo é a regulação dos significados jurídicos por normas substanciais (com base no princípio da legalidade substantiva), que limitam todos os ramos do governo, em primeiro lugar, para garantir as liberdades individuais e, depois, vincular o conteúdo do direito positivo para garantir a efetividade dos direitos fundamentais (liberdades, direitos civis, direitos políticos, direitos sociais).

As premissas da doutrina garantista do direito também estão presentes na doutrina do núcleo essencial dos direitos fundamentais, já devidamente assentada no direito constitucional comparado. Afirma-se, no direito positivo, na doutrina e na jurisprudência de democracias constitucionais que adotam essa linha teórica, que os elementos essenciais dos direitos fundamentais são o limite intransponível das leis e das decisões de Estado. Isso significa que nem sempre os direitos fundamentais têm a mesma força diante de um caso concreto. Sua eficácia pode ser balanceada pelos tribunais a fim de assegurar-Ihes aplicação proporcional às necessidades do caso. Então os direitos fundamentais não têm, sempre e toda a vez, o mesmo peso na solução de um conflito. Mas isso não é o mesmo que relativizar completamente a eficácia desses direitos. O núcleo essencial dos direitos fundamentais é inviolável e, assim, mesmo tendo pesos distintos os direitos fundamentais colidentes e aplicáveis ao caso sempre haverão de influenciar a decisão judicial, e no mais alto grau possível. É simples a conclusão: a tendência interpretativa desse direito constitucional que adota a doutrina do núcleo essencial dos direitos fundamentais é a de maximizar a preservação desses

transposto para o confronto dos poderes privados, apenas que não há uma dimensão constitucional para isso, donde há uma idéia de onipotência do mercado. (FERRAJOLI, 2006) 
direitos pelo estabelecimento de limites severos contra práticas que Ihes ameacem os elementos essenciais.

A Constituição da Alemanha, ao regular a restrição dos direitos fundamentais, em seu Artigo 19, item 2, fixa com muita clareza, abrangência ilimitada e objetividade, que em nenhum caso um direito fundamental poderá ser afetado em seu núcleo essencial. A Constituição de Portugal, na mesma linha, impõe, em seu Artigo 18, 3, que as leis restritivas de direitos, liberdades e garantias têm de revestir caráter geral e abstrato, não podem ter efeito retroativo e nem diminuir a extensão e o alcance do conteúdo essencial dos preceitos constitucionais. A Carta espanhola, ao regular as liberdades e direitos fundamentais, estabelece, em seu Art. 53, que os direitos e liberdades vinculam todos os poderes públicos e que só a lei poderá regular o exercício dos direitos e liberdades, mas, mesmo as leis, precisam respeitar o conteúdo essencial dos direitos e liberdades.

Essas interpretações dos direitos fundamentais já foram reconhecidas pelo Supremo Tribunal Federal em muitos importantes precedentes:

[E]mbora o texto constitucional brasileiro não tenha estabelecido expressamente a ideia de um núcleo essencial, é certo que tal princípio decorre do próprio modelo garantístico utilizado pelo constituinte (HC 82.959, 23.03.2006, Rel. Marco Aurélio. Voto de Gilmar Mendes).

Entendimentos recentes da Corte têm afirmado, nessa linha, que até mesmo as normas Constitucionais dotadas de eficácia programática vinculam o Estado-Juiz quando se trata de afirmar a eficácia do núcleo essencial dos direitos fundamentais.

O caráter programático da regra inscrita no art. 196 da Carta Política - que tem por destinatários todos os entes políticos que compõem, no plano institucional, a organização federativa do Estado Brasileiro, não pode converter-se em promessa constitucional inconseqüente, sob pena de o poder público, fraudando justas expectativas nele depositadas pela coletividade, substituir, de maneira ilegítima, o cumprimento de seu impostergável dever, por um gesto irresponsável de infidelidade governamental ao que determina a própria Lei Fundamental do Estado. (RE 232.335-RS, Rel. Celso de Mello, e RE 271286-RS. Rel. Celso de Mello.12.09.2000. $2^{\mathrm{a}}$ turma. Unânime)

É seguro, então, que restrições a direitos fundamentais, como as implementadas pela Lei da ficha limpa, têm sua legitimidade dependente de razoável solução argumentativa, pois a interpretação de direitos fundamentais reclama ponderação e esta, por sua vez, a aplicação do princípio da proporcionalidade, sem o qual não há interpretação razoável desses direitos.

[A] doutrina constitucional mais moderna enfatiza que, em se tratando de imposição de restrições a determinados direitos, deve-se 
indagar não apenas sobre a admissibilidade constitucional da restrição eventualmente fixada (reserva legal), mas também sobre a compatibilidade das restrições estabelecidas com o princípio da proporcionalidade.

Essa orientação, que permitiu converter o princípio da reserva legal (Gesetzesvorbehalt) no princípio da reserva legal proporcional (Vorbehalt des verhältnismässigen Gesetzes), pressupõe não só a legitimidade dos meios utilizados e dos fins perseguidos pelo legislador, mas também a adequação desses meios para consecução dos objetivos pretendidos (Geeignetheit) e a necessidade de sua utilização (Notwendigkeit oder Erforderlichkeit).

(STA 233 / RS - Suspensão de Tutela Antecipada. Rel: Min. GILMAR MENDES (Presidente) Julg.: 27/04/2009.)

Vê-se que a correta interpretação dos direitos fundamentais não pode ser justificada pela falta de perspectiva doutrinária ou de direito positivo, pois o sistema atual de direitos fundamentais (legislação, doutrina e jurisprudência) fornece todos os elementos para que o Judiciário mobilize as devidas técnicas interpretativas para garantir o núcleo essencial desses direitos constitucionais.

\section{GARANTIAS FUNDAMENTAIS APLICÁVEIS A CIDADÃOS NO PLENO EXERCÍCIO DE SUAS LIBERDADES FUNDAMENTAIS, A CANDIDATOS EM CAMPANHA ELEITORAL E A REPRESENTANTES ELEITOS}

Até a data da publicação deste trabalho, o tema da presunção da não culpabilidade foi tratado pelo Poder Legislativo e pelo Tribunal Superior Eleitoral como algo estranho ao debate da Lei da ficha limpa. Mesmo nas discussões travadas no Supremo Tribunal Federal houve pouco aprofundamento da matéria, ainda que tenha sido bem relevada nos votos de divergência aos dos relatores Carlos Ayres Britto e Joaquim Barbosa, proferidos nas ações que serão analisadas a seguir.

O pouco desenvolvimento da questão de aplicar-se, ou não, o princípio da presunção de não culpabilidade em matéria eleitoral parece exigir mais atenção para a sensibilidade do tema a outras áreas do direito, além da penal stricto sensu. Para bem compreender qual é o caso de aplicação do princípio da não culpabilidade no campo dos direitos políticos, parece instrutivo começar por reconhecer três fases distintas quanto ao exercício desses direitos.

A primeira fase do exercício dos direitos políticos está ligada às condições de formação da vontade política soberana do Estado e é composta por pessoas naturais que adquiriram o status de cidadãos. Os cidadãos, unidos pelo mesmo ordenamento jurídico, formam o populo e têm, por isso, constitucionalmente protegidas algumas liberdades cívicas básicas dos regimes republicanos, como as de: 1) expressar opiniões; 2) de influenciar os demais; e 3) o de obter capacidade política para participar da formação da vontade soberana do Estado (ROCHA, 1997, p. 131). Cidadãos dotados de capacidade política para participar da formação da vontade soberana do Estado são os 
que podem manifestar suas preferências políticas por todas as formas admitidas de sufrágio (capacidade ativa), e por todas as formas plurais, competitivas e abertas de disputar apoio e de se constituir em líder político com a formal inscrição pública de sua candidatura - (capacidade passiva). Nessa primeira fase, em regimes republicanos, onde vige o primado da soberania e do autogoverno popular, o indivíduo está no gozo de um status civitatis com natureza de liberdade individual geral de ação política que se deduz de seu status personae. Como todos os demais direitos personalíssimos, também essa liberdade geral de ação política, traduzida pelo direito de expressar opiniões, de influenciar os demais e de competir pela preferência dos demais, é a essência dos demais direitos políticos, e está protegida pelas rígidas garantias constitucionais aplicáveis às liberdades individuais, aos direitos civis, aos direitos sociais e aos direitos coletivos.

Essas liberdades cívicas fundamentais são um tipo de liberdades positivas (ALEXY, 2008, p. 234), isso quer dizer que são um direito de agir na vida pública sem embaraços desarrazoados; são franquias conferidas pelo direito constitucional. Esse status civitatis, que em sentido positivo é um direito de ação política; é também, em sentido negativo, uma garantia, verdadeiro direito de defesa - no sentido que lhe empresta Alexy - contra causas inconstitucionais - jurisdicionais, normativas ou administrativas - que violem ${ }^{7}$ sua liberdade jurídica geral de ação.

A segunda fase dos direitos políticos se inicia com o ato formal de alistamento eleitoral (capacidade ativa), ou com o ato formal de registro de candidatura (capacidade passiva). A partir do alistamento eleitoral ou do registro de candidatura o cidadão adquire capacidade eleitoral (ativa e passiva) para participar do processo eleitoral, pois adquire o direito de eleger e de disputar eleições. A partir desses atos formais o status civitatis, que é liberdade cívica geral, é disciplinado, restringido e evolui para um novo patamar: o status de eleitor ou de candidato. A regulação das disputas entre partidos e candidatos não pode ser concebida como uma violação da, ou interdição na liberdade geral de ação política, antes referida. É apenas uma restrição dessa liberdade, justificável na medida em que está a serviço da justa (equitativa) competição eleitoral. A disciplina jurídica da disputa eleitoral em democracias constitucionais deve estar fundada, por isso, nos princípios da competitividade e da inclusão. O status de candidato, nessas circunstâncias, não é liberdade ou direito fundamental e não se confunde com o status civitatis, que é. Em vista disso, a execução imediata de sentenças condenatórias que afastam candidatos da disputa eleitoral não pode violar, de forma alguma, o núcleo essencial da cidadania política, e são admitidas pelo direito constitucional. Em verdade, medidas judiciais de urgência em processos eleitorais, isto é, inaudita altera pars, desde que isonômicas e a serviço da justa competição, devem ser

${ }^{7}$ É bom destacar que a violação de uma liberdade geral de ação política não é o mesmo que o seu disciplinamento, que se caracteriza como restrição. As violações atingem o núcleo essencial do direito fundamental, eliminam as alternativas de ação. As restrições, não. 
reconhecidas como soluções protetivas da eficácia das condições da competição eleitoral, pois não regulam liberdades, mas direitos.

A terceira fase se inicia com o ato formal de diplomação e investidura no cargo público para o qual o candidato foi eleito. O status civitatis evolui para outro patamar: o status de representante, que não é direito fundamental e não se confunde, mais uma vez, com o status civitatis, que é. Os direitos de representante não são personalíssimos. São direitos, não liberdades. Em vista disso, a execução imediata de sentenças condenatórias que cassam diplomas eleitorais não são violações do núcleo essencial da cidadania política e são, igualmente, admitidas pelo direito constitucional porque protegem a eficácia das condições da competição eleitoral. E por que não ferem o núcleo essencial de um direito fundamental (status civitatis) não se aplica a esses impedimentos a garantia do trânsito em julgado de sentença condenatória, portanto a presunção de não culpabilidade.

Em síntese, a perda da capacidade eleitoral passiva ou da capacidade representativa não fere, prima facie, o status civitatis do cidadão e este, e somente este status primeiro, porque fundamental, é protegido pela cláusula do art. $5^{\circ}$. LVII da Constituição da República Federativa do Brasil ${ }^{8}$.

O ex-Procurador-Geral da República, Antonio Fernando Barros e Silva de Souza, sustentou argumento semelhante em parecer apresentado, e acolhido pelo STF, no julgamento da ADI 3592-DF:

Distintas são as situações de inelegibilidade e de captação ilícita de sufrágio, porquanto esta impõe uma sanção que decorre de prática de corrupção eleitoral, enquanto aquela impõe um impedimento, um obstáculo que não se caracteriza como sanção, embora dela possa resultar. Dessa forma, não se pode concluir que a disposição insculpida no artigo 41-A, da Lei no 9.504/97 se apresenta como obstáculo à cidadania passiva, isto é, como espécie de inelegibilidade, porquanto, na realidade, o que fez o legislador foi impor uma forma de sanção ao candidato que vicia a vontade do eleitor, através da doação, oferecimento, promessa ou entrega de bem ou vantagem pessoal de qualquer natureza, inclusive emprego ou função pública, e a punição é restrita ao pleito em que ocorreu a captação ilícita (grifo nosso).

A questão está bem posta. Havendo cidadão livre, têm liberdade geral de ação política, havendo candidato registrado, poderá ser eleito ou não;

\footnotetext{
${ }^{8}$ O Tribunal Superior Eleitoral já possui jurisprudência ilustrativa desse entendimento Ac. n. 25.241, de 22.9.2005, rel. Min. Humberto Gomes de Barros; no mesmo sentido o Ac. n. 882, de 8.11.2005, rel. Min. Marco Aurélio; Ac. n. 25.295, de 20.9.2005, rel. Min. Cesar Asfor Rocha; Ac. n. 5.817, de 16.8.2005, rel. Min. Caputo Bastos; Ac. n. 25.215, de 4.8.2005, rel. Min. Caputo Bastos; no mesmo sentido o Ac. n. 25.289, de 25.10.2005, do mesmo relator; Ac. n. 25.227, de 21.6.2005, Rel. Min. Gilmar Mendes; Ac. n. 4.659, de 19.8.2004, Rel. Min. Peçanha Martins; Ac. n. 612, de 29.4.2004, rel. Min. Carlos Velloso; Ac. n. 21.221, de 12.8.2003, rel. Min. Luiz Carlos Madeira; Ac. n. 21.169, de 10.6.2003, rel. Min. Ellen Gracie; Ac. n. 21.248, de 3.6.2003, Rel. Min. Fernando Neves; Ac. n. 19.644, de 3.12.2002, Rel. Min. Barros Monteiro.
} 
se houver candidato eleito poderá ser cassado ou impedido. Não há como aplicar aos dois últimos status a rigidez do regime de garantias inerentes aos direitos personalíssimos, como é o caso do trânsito em julgado que se aplica, sempre, aos cidadãos em seu status civitatis.

É sutil a diferença, mas muito relevante. Candidatos registrados ou eleitos estão sujeitos a um regime de garantias distinto do aplicável aos cidadãos no pleno exercício de suas liberdades fundamentais.

A rigidez da presunção de não culpabilidade se aplica, sempre, e prioritariamente, como garantia do núcleo essencial das liberdades fundamentais (QUINTARD-MORENAS, 2010, p.133), e é coerente com o princípio da máxima eficácia das normas de direitos fundamentais, tão propugnada pelo pensamento constitucional atual (ALEXY, 2008; CADEMARTORI, 2010; STRAPAZZON, 2009; MARTEL, 2009).

Despojar o cidadão, pelo recebimento de denúncia contra ele oferecida pelo Ministério Público, do direito a concorrer a cargo eletivo importa em privá-lo, sem julgamento, de status ligado ao seu direito de cidadania, o status activae civitatis. Implica isso, inequivocamente, cominar-Ihe pena, punição ou castigo, independente do "due processo of law" [...] equivale, isso, a sujeitá-lo a pena acessória sem pena principal [...].

(Min. Leitão de Abreu. RE 86297, p. 661. 10.11.1976)

\section{NÃO CULPABILIDADE: PARA ALÉM DO DIREITO PENAL EM SENTIDO ESTRITO}

Com a instauração, em nosso País, de uma ordem plenamente democrática, assim consagrada pela vigente Constituição, intensificouse o círculo de proteção em torno dos direitos fundamentais, qualquer que seja o domínio de sua incidência e atuação, compreendidos, para efeito dessa tutela constitucional e em perspectiva mais abrangente, todos os blocos normativos concernentes aos direitos individuais e coletivos, aos direitos sociais e aos direitos políticos, em ordem a conferir-Ihes real eficácia [...].

[M]esmo tratando-se do bloco pertinente aos direitos políticos [...], não se pode, como corretamente adverte o eminente Ministro Eros Grau, buscar interpretação que substitua [...] a racionalidade formal do direito, que se funda nas instituições e nas leis, por critérios impregnados de valorações que culminam por afetar a segurança e a certeza jurídicas, com sério risco à integridade do próprio sistema de garantias construído pela Constituição, cuja normatividade não pode ser potencializada nem tornada relativa, [...] por uma explicitação teórica de distintos blocos de direitos e preceitos (STF. ADPF 144, Rel. Min. Celso de Mello, grifo nosso)

No direito comparado colheremos bons exemplos da rigidez da presunção de não culpabilidade. Em primeiro lugar, perceberemos que o princípio tem 
duas perspectivas: 1) é regente do direito probatório; e 2) é direito subjetivo garantidor da liberdade individual (LAZERGES, 2004, p.128). Poderemos ver também que essa presunção não tem aplicação limitada a matérias estritamente penais, e poderemos constatar, da mesma maneira, que a desconstituição dessa presunção depende, em todos os casos relevantes, de decisões definitivas ou transitadas em julgado, tal como prescrito pelo modelo rígido adotado pelo art. $5^{\circ}$. LVII, da Carta Brasileira.

O Artigo 32 da Constituição de Portugal, que trata das Garantias de processo criminal, regula, em seu item 2 que:

Todo o arguido se presume inocente até ao trânsito em julgado da sentença de condenação, devendo ser julgado no mais curto prazo compatível com as garantias de defesa.

O Art. 24 da Constituição da Espanha define que:

[T]odos tienen derecho al Juez ordinario predeterminado por la ley, a la defensa y a la asistencia de letrado, a ser informados de la acusación formulada contra ellos, a un proceso público sin dilaciones indebidas y con todas las garantías, a utilizar los medios de prueba pertinentes para su defensa, a no declarar contra sí mismos, a no confesarse culpables y a la presunción de inocencia.

Em nota explicativa ao Art. 24, acima transcrito, publicada no site oficial do Congresso dos Deputados da Espanha, lê-se que:

En palabras de la ya citada STC 81/1998 (F. 3) la presunción de inocencia opera [...] como el derecho del acusado a no sufrir una condena a menos que la culpabilidad haya quedado establecida más allá de toda duda razonable.

O Art. 42 da Carta da Polônia:

Todos devem ser presumidos inocentes até que sua culpa seja determinada por uma decisão judicial definitiva (tradução nossa)

O Art. 27 da Constituição Italiana:

A responsabilidade penal é pessoal. O imputado não será considerado culpado senão depois de sua condenação definitiva (tradução nossa).

Na França, além de ser garantia expressa da Declaração dos Direitos do Homem e do Cidadão, a presunção de não culpabilidade foi inserida também no Código Civil (sic), como direito personalíssimo. 
Art. 9-1, alínea 1 do Code Civil da França:

Todos têm direito à presunção de inocência. Quando uma pessoa é, antes de qualquer condenação, publicamente representada como sendo culpada por atos objetos de inquérito ou de processo, o juiz pode, mesmo em processo sumário, sem prejuízo da reparação pelos danos sofridos, prescrever medidas, tais como a inclusão de uma correção ou um comunicado de imprensa, com o objetivo de conter a violação da presunção de inocência, e às custas da pessoa ou entidade responsável pela agressão (tradução nossa).

A exigência do trânsito em julgado, ou de decisão definitiva, para considerar legítima a desconstituição da presunção de não culpabilidade, como se pode ver, não é uma solução genuinamente brasileira. É, antes disso, postulado característico dos modelos de constitucionalismo rígido. A rigidez constitucional, assim como prevista no direito comparado, é, em primeiro lugar, uma garantia de não retrocesso em matéria de direitos fundamentais.

$\mathrm{Na}$ ordem constitucional brasileira o Constituinte ao instituir a exigência de trânsito em julgado de sentença condenatória, como condição para afastar a presunção de não culpabilidade, não fez outra coisa além de instituir um modelo rígido de proteção dessa liberdade personalíssima e, nessa medida, agiu coerentemente com o regime de direitos fundamentais adotado pela lógica garantista ${ }^{9}$ do sistema constitucional brasileiro.

Vê-se, por tudo isso, que em países de Constitucionalismo rígido, a pretensão de punir ilícitos penais e outras modalidades de infrações, precisa encontrar caminhos que causem o menor dano possível ao núcleo essencial dos direitos fundamentais, razão de ser da rigidez da referida cláusula garantista.

\section{INELEGIBILIDADE NA EVOLUÇÃO JURISPRUDENCIAL DO STF}

No relatório condutor do acórdão da ADPF 144-DF/2008 o Ministro Celso de Mello historia as interpretações constitucionais adotadas pela Corte, em seu passado recente, para o tema da sanção de inelegibilidade em face da presunção de não culpabilidade. Compreender essa evolução é importante, entre outros motivos, porque evidencia o quanto as discussões atuais retomam velhos modelos normativos, intenções políticas e, por via de consequência, submetem-se às mesmas conclusões já encontradas e aplicadas pelo Poder Judiciário. Nas discussões havidas entre os ministros do STF, como se verá, sobressaem as preocupações com a eficácia dos direitos fundamentais em face das pretensões punitivas do Estado e da sociedade.

Vejamos o que escreveu Celso de Mello no caso acima mencionado:

\footnotetext{
${ }^{9}$ Embora o texto constitucional brasileiro não tenha estabelecido expressamente a idéia de um núcleo essencial, é certo que tal princípio decorre do próprio modelo garantístico utilizado pelo constituinte (HC 82.959, 23.03.2006, Rel. Marco Aurélio. Citação do voto de Gilmar Mendes. Caso dos crimes hediondos).
} 
A Carta Federal de 1969, outorgada por um triunvirato militar, que preferiu mascarar o ato de imposição sob a designação formal de Emenda Constitucional $n^{\circ} 01 / 69$, estabeleceu, no art. 151 , em sua redação original, regra que assim disciplinou a matéria em causa, reproduzindo, no que concerne à defesa da probidade administrativa, a cláusula já contemplada na Carta Política de 1967 (art. 148, II):

Art. 151. Lei complementar estabelecerá os casos de inelegibilidade e os prazos dentro dos quais cessará esta, visando a preservar:

I - o regime democrático;

II - a probidade administrativa;

III - a normalidade e legitimidade das eleições contra a influência ou o abuso do exercício de função, cargo ou emprego públicos da administração direta ou indireta, ou do poder econômico; e

IV - a moralidade para o exercício do mandato, levada em consideração a vida pregressa do candidato.

Essa regra da Carta Política de 1969, por sua vez, sofreu alteração, introduzida pela EC $n^{\circ} 08 / 77$, que deu, ao referido art. 151, a seguinte redação:

"Art. 151. Lei complementar estabelecerá os casos de inelegibilidade e os prazos nos quais cessará esta, com vistas a preservar, considerada a vida pregressa do candidato:

I - o regime democrático;

II - a probidade administrativa;

III - a normalidade e legitimidade das eleições contra a influência ou o abuso do exercício de função, cargo ou emprego públicos da administração direta ou indireta, ou do poder econômico; e

IV - a moralidade para o exercício do mandato."

Para regulamentar esse preceito constitucional (CF/69,art. 151), foi editada a Lei Complementar $n^{\circ}$ 05/70, que, dentre as várias hipóteses de inelegibilidade, previu a perda da capacidade eleitoral passiva em decorrência da mera instauração de processo judicial contra qualquer potencial candidato que houvesse incidido em suposta prática de determinadas infrações penais.

Eis o teor dessa norma legal, inscrita em referido diploma legislativo:

"Art. $1^{\circ}$ - São inelegíveis:

I - para qualquer cargo eletivo:

$[\ldots]$

n) os que tenham sido condenados ou respondam a processo judicial, instaurado por denúncia do Ministério Público recebida pela autoridade judiciária competente, por crime contra a segurança nacional e a ordem política e social, a economia popular, a fé pública e a administração pública, o patrimônio ou pelo delito previsto no art. 22 desta Lei Complementar, enquanto não absolvidos ou penalmente reabilitados;" 
Bastava, portanto, para gerar situação de inelegibilidade, o simples recebimento de uma denúncia, por alegado cometimento de certos ilícitos penais.

Essa cláusula legal provocou, mesmo sob a égide de um regime autoritário, amplo debate em torno de sua constitucionalidade, valendo relembrar que o $\mathrm{E}$. Tribunal Superior Eleitoral pronunciou-se, diversas vezes, sobre a matéria, reconhecendo, num momento inicial, a validade constitucional da regra legal em questão, até que o eminente Ministro XAVIER DE ALBUQUERQUE, em voto que prevaleceu no julgamento do REspe 4.221/RS, dissentiu dessa orientação jurisprudencial, "[...] pela razão de considerar inconstitucional o art. 1', inciso I, letra ' $n$ ', da Lei Complementar $n^{\circ} 5$, de acordo com o voto que ontem proferi neste Tribunal".

Cabe rememorar, neste ponto, por relevante, os fundamentos pelos quais o eminente Ministro XAVIER DE ALBUQUERQUE, mesmo em votos vencidos, como aquele proferido no julgamento, pelo TSE, do Recurso Ordinário $n^{\circ} 4.189 / R J$, entendia, com absoluta razão, ser inconstitucional a norma inscrita no art. $1^{\circ}$, inciso I, alínea "n", da Lei Complementar $n^{\circ}$ 5/70:

[...] Por que admitir que o simples fato de pendência de um processo, com denúncia oferecida e recebida, pese indelevelmente sobre a moralidade de alguém, a ponto de the acarretar o ônus brutal da inelegibilidade? Não posso admitir. E não posso admitir, porque estou lidando com princípios eternos, universais, imanentes, que não precisam estar inscritos em Constituição nenhuma. Mas, por acaso, esse princípio, se não está expresso na Constituição da República Federativa do Brasil, está inscrito, de modo o mais veemente e peremptório, na famosa 'Declaração Universal dos Direitos do Homem', que é capítulo de uma inexistente, mas evidente Constituição de todos os povos. O Brasil contribuiu, com sua participação e voto, para que a Terceira Assembléia Geral das Nações Unidas, há mais de 25 anos, aprovasse uma 'Declaração Universal dos Direitos do Homem', e essa declaração insculpiu, no primeiro inciso do seu art. 11, esta regra de verdadeira Moral e do mais límpido Direito:

'Todo homem acusado de um ato delituoso tem o direito de ser presumido inocente até que a sua culpabilidade tenha sido provada, de acordo com a lei, em julgamento público, no qual the tenham sido asseguradas todas as garantias necessárias à sua defesa'.

Este princípio é inerente ao nosso regime, pois está compreendido entre aqueles que a Constituição adota. Não precisa ele estar nela explicitado, em letra de forma. Basta que o comparemos com o regime da Constituição brasileira [...], tanto que ela o inscreve como um daqueles bens jurídicos que se devem preservar no estabelecimento das inelegibilidades. Basta que comparemos o princípio com o regime, a vermos se há entre eles coincidência ou repulsa. É evidente que a coincidência é a única alternativa. O Brasil proclamou, num documento internacional e no regime que adotou, essa verdade universal, que, insisto, não precisa estar inscrita em lei nenhuma, porque é princípio 
ético e jurídico, imanente. $\mathbf{O}$ fato de alguém responder a processo criminal adere, objetivamente, à sua vida. Ninguém, que respondeu a um processo criminal, retira jamais esse episódio da sua história pessoal. Mas não pode ele, por si só, comprometer a moralidade do cidadão, que deve ser presumido inocente enquanto não for julgado culpado." (grifei)

É certo, no entanto, que o Supremo Tribunal Federal, ao julgar o RE 86.297/SP, Rel. Min. THOMPSON FLORES, proclamou a validade constitucional da norma legal em questão.

Torna-se importante registrar, [...] que os próprios curadores do regime militar, já no Governo do Presidente Figueiredo, decidiram banir semelhante regra jurídica do sistema de direito positivo nacional, fazendo-o mediante a edição da Lei Complementar $n^{\circ} 42 / 82$, cujo art. $1^{\circ}$ assim dispunha:

"Art. $1^{\circ}$ - As alíneas $b$ e $n$ do inciso I do art. $1^{\circ}$ da Lei Complementar $\mathrm{n}^{\circ} 5$, de 29 de abril de 1970, passam a vigorar com a seguinte redação:

'Art. $1^{\circ}-[\ldots]$

$\mathrm{I}-[\ldots]$

n) os que tenham sido condenados (Vetado) por crime contra a segurança nacional e a ordem política e social, a economia popular, a fé pública, a Administração Pública e o patrimônio, ou pelo delito previsto no art. 22 desta Lei Complementar, enquanto não penalmente reabilitados; [...]."' (grifei)

Devo observar, por necessário, que o Supremo Tribunal Federal, ao decidir o RE 99.069/BA, Rel. Min. OSCAR CORRÊA, e tendo presente a alteração introduzida pela Lei Complementar $n^{\circ} 42 / 82$, que condicionava o reconhecimento da inelegibilidade de qualquer candidato à existência de sentença condenatória, expressamente proclamou que a perda da capacidade eleitoral passiva dependeria do trânsito em julgado da condenação, não bastando, para tanto, a mera prolação de uma sentença.

Extremamente esclarecedoras, e muito atuais, as razões com que o eminente e saudoso Ministro OSCAR CORRÊA, na condição de Relator, fundamentou, em referido julgamento, o seu douto voto:

"[...] Na verdade, quando a lei - qualquer que seja - se refere a condenação, há que se entender condenação definitiva, transitada em julgado, insuscetível de recurso que a possa desfazer.

Nem se alegue [...] que 'essa interpretação era a que se coadunava com a moralidade que o art. 151, IV da Constituição visa a preservar': há que preservar a moralidade, sem que, sob pretexto de defendê-la e resguardá-la, se firam os direitos do cidadão à ampla defesa, à prestação jurisdicional, até a decisão definitiva, que o julgue, e condene, ou absolva.

Não preserva a moralidade interpretação que considera condenado quem o não foi, em decisão final irrecorrível. Pelo contrário: a ela se opõe, porque põe em risco a reputação de alguém, que se não 
pode dizer sujeito a punição, pela prática de qualquer ilícito, senão depois de devida, regular e legalmente condenado, por sentença de que não possa, legalmente, recorrer.

[...] Veja-se a hipótese dos autos: julgado inelegível, em virtude de condenação, no Juízo de $1^{\circ} \mathrm{grau}$, teve o Recorrente negado o registro de sua candidatura a deputado federal. Conseguida, agora, a absolvição, e admitindo-se o provimento deste recurso - argumento que me permito expender - à véspera do pleito, já se lhe terá causado mal irreparável: não pôde concorrer à eleição, à qual se candidatara, e nem há reparação possível, de qualquer espécie, a esse mal.

[...] Quando o art. 151 delegou à legislação complementar estabelecer os casos de inelegibilidades e os prazos nos quais cessará esta, não Ihe autorizou alterar o sistema legal brasileiro (e, pode dizer-se, universal) para considerar condenação a que, desde logo, em primeiro grau, se imponha, sem que trânsito em julgado (RE 99.069/BA, Rel. Min. OSCAR CORRÊA - grifo nosso)

\section{HIPÓTESES DE INELEGIBILIDADES COM NATUREZA SANCIONATÓRIA}

A inelegibilidade é conceito equívoco, do modo como está posto na LC 64/90 (COSTA 2009, 147-174). Seria melhor a jurisprudência reconhecer que a LC 64/90 institui hipóteses impeditivas de candidatura, pois a inelegibilidade é impedimento que se aplica apenas a quem teve candidatura deferida.

$\mathrm{O}$ indeferimento judicial do registro de candidatura, com fundamento na Lei 64/90, não é, necessariamente, uma antecipação de juízo de culpabilidade penal. Esse argumento vem sendo muito usado pelos defensores da Lei da ficha limpa, como se não fosse do conhecimento público. O que precisa ser realçado é que as hipóteses legais de indeferimento de registro de candidatura também contemplam situações que não dizem respeito a condutas penalmente censuradas. Por exemplo, os analfabetos, pelo simples fato de não poderem comprovar sua condição de letrados, não podem registrar candidatura a qualquer cargo. Ainda, várias autoridades federais diretamente ligadas à Presidência da República, até 6 (seis) meses depois de afastados definitivamente de seus cargos e funções, também estão impedidas de se candidatar a Presidente. O mesmo se aplica aos cargos simétricos vinculados a Governadores de Estado; por fim, o cônjuge e os parentes, consanguíneos ou afins, até o segundo grau ou por adoção, do Presidente da República, de Governador de Estado ou Território, do Distrito Federal, de Prefeito ou de quem os haja substituído dentro dos 6 (seis) meses anteriores ao pleito, salvo se já titular de mandato eletivo e candidato à reeleição também não podem se candidatar. Vê-se que essas hipóteses, todas da atual Lei das Inelegibilidades, são impeditivas de registro de candidatura e não têm qualquer natureza de sanção penal. A causa jurídica da proibição não é uma conduta vedada pelo ordenamento penal. 
É recomendável muita prudência, no entanto, para evitar generalizações. É que a LC 64/90 tem, sobretudo depois das inovações promovidas pela Lei da ficha limpa, hipóteses de inelegibilidade com natureza de sanção penal. São as inelegibilidades instituídas como reação/consequência a práticas de atos ilícitos por aqueles que desejam se candidatar. Essas hipóteses legais, ao contrário das outras, têm forma e conteúdo de reação punitiva do Estado. É o caso, precisamente, das alíneas "d" e "e" do Art. $1^{\circ}$. da atual Lei Complementar 64/1990, que têm o seguinte teor:

\section{Art. $1^{\circ}$ São inelegíveis:}

d) os que tenham contra sua pessoa representação julgada procedente pela Justiça Eleitoral, em decisão transitada em julgado ou proferida por órgão colegiado, em processo de apuração de abuso do poder econômico ou político, para a eleição na qual concorrem ou tenham sido diplomados, bem como para as que se realizarem nos 8 (oito) anos seguintes;

e) os que forem condenados, em decisão transitada em julgado ou proferida por órgão judicial colegiado, desde a condenação até o transcurso do prazo de 8 (oito) anos após o cumprimento da pena, pelos crimes [que elenca].

Se nem todas as hipóteses impeditivas de candidatura têm natureza sancionatória, como se disse acima, fica claro agora que nem todas têm natureza apenas preventiva. É que "toda inelegibilidade aplicada como decorrência de atos ilícitos eleitorais tem natureza de sanção; é uma punição [...]. Aliás, a distinção entre inelegibilidade inata e inelegibilidade cominada é precisamente esta [...]" (COSTA, 2010).

$\mathrm{O}$ ato de indeferimento de registro de candidatura, fundado em decisão judicial decorrente do reconhecimento de ato ilícito, porém não transitada em julgado, sempre é uma privação cercada das garantias jurídicas que se aplicam contra sanções de natureza penal. En bref, para o Estado vedar o exercício de uma liberdade política fundamental (como é a de obter capacidade eleitoral para disputar eleições), com base em prática de atos ilícitos, precisa respeitar o due process of law.

$\mathrm{O}$ ato de indeferimento do registro de candidatura tem natureza administrativa (mas é praticado por um juiz eleitoral investido de poder de imperium, portanto, é ato obrigatório e coativo). $\mathrm{O}$ ato de indeferimento, além disso, impede, plenamente, o exercício da liberdade cívica de alguém se apresentar para ser líder político e, assim, agride o núcleo essencial dos direitos políticos constitucionais, porque suspende uma liberdade cívica fundamental prevista, inclusive, em tratados internacionais firmados pelo $\mathrm{Brasil}^{10}$.

${ }^{10}$ Art. 25 do Pacto Internacional sobre Direitos Civis e Políticos, adotado pela XXI Sessão da Assembléia-Geral das Nações Unidas, em 16 de dezembro de 1966 e posto em vigor, no Brasil, pelo Decreto n. 592, de 6 de julho de 1992. 
Pelo que já se viu até aqui, a lei que suspende uma liberdade cívica fundamental de quem tem contra si condenação judicial fundada em ato ilícito e não transitada em julgado, como quer a Lei da ficha limpa, institui uma suspensão inconstitucional posto que institui uma punição preventiva, o que é contrário aos princípios mais caros da tradição liberal, humanitária e constitucional.

\section{A LEI DA FICHA LIMPA NAS DECISÕES RECENTES DO TSE E STF}

\subsection{Observação da anterioridade eleitoral}

O princípio da anterioridade ou anualidade eleitoral está previsto no art. 16 da Constituição Federal, com a seguinte redação:

Art. 16. A lei que alterar o processo eleitoral entrará em vigor na data de sua publicação, não se aplicando à eleição que ocorra até um ano da data de sua vigência.

O Tribunal Superior Eleitoral (TSE) foi questionado (Consulta 112026.2010.6.00.0000 - CLASSE 10) sobre a aplicabilidade imediata da Lei da ficha limpa (Lei Complementar n. 135, de 04/06/2010, DOU de 07/06/2010) que entrou em vigor na data da sua publicação, em especial quanto às garantias impostas pelo princípio constitucional da anterioridade eleitoral. Afinal, uma lei eleitoral que dispõe sobre inelegibilidades e que tem sua entrada em vigor antes do prazo de 5 de julho ${ }^{11}$, poderia ser aplicada nas eleições gerais de 2010?

O TSE entendeu que no tocante à aplicação do princípio constitucional da anterioridade eleitoral, a orientação do Supremo Tribunal Federal tem sido a de evitar leis que criam manobras ou que possam beneficiar determinado segmento envolvido na disputa.

Em que pese tal precaução, o STF já decidiu um caso (RE 129.392, 1990) com fundamento no vácuo legislativo, isto é, na necessidade de superar o princípio constitucional da anterioridade eleitoral para assegurar a eficácia do Art. $14 \S 9^{\circ}$. da CRFB, ou seja, para assegurar a existência de, ao menos, uma lei de inelegibilidades. Isso ocorreu nas eleições de 1992. O mesmo raciocínio se aplicaria à Lei da ficha limpa, que foi publicada antes das convenções partidárias e que, por conseguinte, não afetou o andamento da eleição. O TSE entendeu que se a lei entrar em vigor antes das convenções partidárias, ela não altera o processo eleitoral. Além disso, o TSE entendeu que as inovações trazidas pela LC no 135/2010 teriam natureza exclusivamente material e em nada se identificariam com as de processo eleitoral, em sentido estrito, como exige o referido artigo 16 da Constituição.

\footnotetext{
${ }^{11}$ Veja o que dispõe a Lei $n^{\circ} 9.504$, de 30 de setembro de 1997, a Lei Geral das Eleições: Art. 11. Os partidos e coligações solicitarão à Justiça Eleitoral o registro de seus candidatos até as dezenove horas do dia 5 de julho do ano em que se realizarem as eleições. Art. 36. A propaganda eleitoral somente é permitida após o dia 5 de julho do ano da eleição. Art. 57-A. É permitida a propaganda eleitoral na internet, nos termos desta Lei, após o dia 5 de julho do ano da eleição. (Incluído pela Lei no 12.034, de 2009)
} 
Em síntese, de acordo com precedentes do STF (ADI 3.741/DF), se a lei nova não rompe a igualdade de participação dos partidos políticos e dos respectivos candidatos no processo eleitoral, se não introduz deformação de modo a afetar a normalidade das eleições, se não é uma alteração motivada por propósito casuístico, então ela não viola o princípio constitucional da anterioridade eleitoral.

\subsection{Aplicação retroativa e respeito à presunção de inocência}

O Tribunal Superior Eleitoral (TSE) definiu, em 17/6/2010, no julgamento da Consulta 1.147-09/DF, Rel. Min. Arnaldo Versiani, por 6 (seis) votos a 1(um), que a Lei da ficha limpa se aplica, inclusive, a situações anteriores. O relator assentou que inelegibilidade não é pena e que, assim como a falta de qualquer condição de elegibilidade, nada mais é do que uma restrição temporária à possibilidade de qualquer pessoa exercer mandato. Assim, como as novas disposições legais atingem, igualmente, todos os que, no momento do pedido de registro, incidiram em alguma causa de inelegibilidade, não se poderia cogitar de direito adquirido às causas de inelegibilidade anteriormente previstas. Por fim, abordou o tema das decisões sem trânsito em julgado, assentando que a sua incidência não significa que se esteja antecipando um cumprimento de pena e que, por isso, não haveria ofensa ao princípio da presunção de inocência. Destacou, ainda, o disposto no art. $3^{\circ}$ da nova lei que permite a suspensão, em caráter cautelar, da inelegibilidade sempre que existir plausibilidade da pretensão do recurso.

Portanto, todos os políticos condenados por decisão colegiada, antes ou depois da publicação da Lei da ficha limpa, em 7 de junho, ficariam impedidos de se candidatar para o pleito de outubro de 2010. Os ministros decidiram também que ficariam inelegíveis todos aqueles que renunciaram para evitar cassação, bem como os cassados pela Justiça Eleitoral por irregularidades cometidas nas eleições de 2006. A síntese: ao ver do TSE, como as inelegibilidades não constituem pena, a Lei da ficha limpa pode retroagir e agravar uma situação anterior à sua vigência.

8.3. Ponderação favorável à moralidade e à probidade administrativa

Em defesa da Lei da ficha limpa, há também vozes eivadas de ética republicana, como é o caso do Min. Joaquim Barbosa, do STF. Para Barbosa, relator do RE 631.102/PA, conhecido como "caso Jader Barbalho", a Lei da ficha limpa deve ser analisada a partir da valorização da moralidade e da probidade no trato da coisa pública, sob uma ótica de proteção dos interesses públicos e não dos puramente individuais. ${ }^{12}$

Noutro caso, o Ministro Levandowski afirmou que a referida Lei

[T]eve em mira proteger valores constitucionais que servem de arrimo ao próprio regime republicano, abrigados no $\S 9^{\circ}$ do art. 14 da Constituição, que integra e complementa o rol de direitos e garantias

${ }^{12}$ Ver Informativo do STF, n. 606 (out/2010)

Direitos Fundamentals E JUSTIÇA N 14 - JAN./MAR. 2011 
fundamentais estabelecidos na Lei Maior. (TSE. Voto-vista do Min. Ricardo Levandowski. Recurso Ordinário 4336-27-27-CE. Rel. Marcelo Ribeiro. p.15).

Carlos Ayres Britto, no voto proferido no caso "Joaquim Roriz" (630.147/DF), sustentou que a Constituição objetivara resgatar o significado original do termo "candidato", que adviria de cândido, puro, limpo no sentido ético. Daí a necessidade da criação de institutos como o da inelegibilidade, os quais tornariam os políticos dignos da política ou que salvariam a política dos políticos avessos aos princípios da moralidade e da probidade administrativa, e da não incidência do abuso do poder político ou econômico. Realçou que valores como o da probidade administrativa e o da moralidade para o exercício do mandato não comportariam procrastinação ou "quarentena"13.

\subsection{Razões de divergência}

No caso Joaquim Roriz, o Ministro Dias Toffoli proveu os recursos, exclusivamente no que se refere à afronta ao art. 16 da Constituição Federal. Entendeu que embaraços ao direito à elegibilidade deveriam ser compreendidos sob perspectiva histórica, especialmente quando razões de natureza moral poderiam ser invocadas para fins de exclusão política de segmentos incômodos ao regime. A seu ver, o princípio da anterioridade das leis eleitorais não distinguiria as espécies de leis nem o conteúdo dos seus dispositivos, sendo, pois, genérico, direto e explícito. $\mathrm{O}$ art. 16 da Constituição Federal foi interpretado por ele como uma garantia de segurança jurídica e de devido processo legal e visaria evitar a quebra da previsibilidade das condições subjetivo-políticas dos candidatos. Os Ministros Gilmar Mendes, Marco Aurélio, Celso de Mello e Cezar Peluso seguiram a divergência e afirmaram, ainda, que a situação advinda com a renúncia de Joaquim Roriz ao cargo de parlamentar - devidamente constituída segundo a legislação da época - não poderia ser alcançada pela LC 135/2010.

No caso Jader Barbalho (RE - 631.102) a divergência ocorreu por parte dos Ministros Dias Toffoli, Gilmar Mendes, Marco Aurélio, Celso de Mello e Cezar Peluso, ao reiterarem posições firmadas no julgamento do aludido RE 630.147/DF. Reputaram que a nova Lei da ficha limpa repercutira em inúmeros julgamentos no processo eleitoral. Acrescentaram que a alínea $\mathrm{k}$ dessa Lei não seria fruto de iniciativa popular, mas resultado de emenda a projeto de lei. Registraram ainda que, quando Jader Barbalho renunciou, em 2001, dentre as consequências previstas para tal ato, não havia a inelegibilidade e que uma lei posterior não poderia buscar um fato pretérito para extrair consequências no presente. Realçaram que a concessão de eficácia retroativa à lei implicaria aplicação casuística e personalizada. Observaram que após a renúncia, Jader Barbalho obtivera da Justiça Eleitoral o deferimento dos registros e respectivas diplomações nas duas eleições seguintes, tendo sido o candidato a Deputado Federal mais votado no Brasil.

${ }^{13}$ Ver RE 630.147/DF, Rel. Min. Ayres Britto. 
9. SENTIDO E ALCANCE DA GARANTIA DO ART. $5^{\circ}$, LVII DA CRFB

Já é tempo de perguntar qual é o alcance do princípio de que ninguém será considerado culpado até o trânsito julgado de sentença penal condenatória. A resposta deve estar respaldada na jurisprudência recente dos tribunais superiores, a fim de propiciar um nível satisfatório de segurança conceitual.

No Tribunal Superior Eleitoral, o Ministro Cesar Peluso enfrentou essa questão da seguinte forma:

Significa uma garantia. Garantia contra o quê? Contra a aplicação de qualquer sanção, entendida como qualquer restrição a qualquer direito do réu, até que advenha uma sentença penal condenatória que transite em julgado e, portanto, significa que nenhuma modalidade de sanção, de restrição, de conseqüência gravosa ao patrimônio jurídico do réu, concebido no largo sentido da esfera de seus direitos de todas as índoles, nenhuma dessas pode ser admitida a título de juízo de culpabilidade senão depois do trânsito em julgado de sentença penal condenatória. (grifo nosso). (TSE. RO 1.069/RJ. Rel. Min. Marcelo Ribeiro. Voto do Min. Cesar Peluso)

Ainda que o direito eleitoral esteja sob a influência do princípio da precaução, é preciso reconhecer que essa é apenas uma característica prima facie desse subsistema. É um traço que pode ser alterado se normas de outra natureza (sancionadoras, e não só preventivas) forem inseridas nesse campo. Grave é perceber que o direito eleitoral, por ser regido pela precaução, não está imune à recepção de normas sancionadoras. Como revela a doutrina das sanções jurídicas, uma privação de bem ou restrição a direitos pode ter origem em qualquer norma do ordenamento jurídico, não precisa advir diretamente de um subsistema onde a norma sancionadora faz incidir suas consequências. Noutras palavras, a natureza jurídica das normas não é definida pela sua localização no interior do ordenamento jurídico (se está neste ou naquele subsistema), mas pela natureza das consequências que institui.

A orientação do Min. Peluso ajuda a ver que já não é razoável supor, como fazia a vetusta doutrina dos princípios autônomos dos microssistemas jurídicos, que o sistema de direito eleitoral não possa ser afetado por normas de natureza sancionadora (privação ou restrição de liberdades, privação de bens) nem é certo dizer, por conseguinte, que o princípio da não culpabilidade se aplica, exclusivamente, aos domínios do direito penal stricto sensu.

Algumas hipóteses de inelegibilidade podem ter natureza sancionatória quando, como já foi dito, o suporte fático da inelegibilidade for a prática de ato ilícito reconhecido em sentença condenatória. $E$ isso é, precisamente, o que foi instituído pela Lei da ficha limpa, por exemplo, pela atual redação da alínea "d" do Art. $1^{\circ}$ da LC 64/90.

No parecer emitido pela Comissão de Constituição, Justiça e Cidadania, cujo relator foi ao atual Ministro da Justiça, Deputado José Eduardo Cardozo, publicado em 28.04.2010, lê-se que: 
Ao contrário do que ocorre com os princípios do devido processo legal (CF, art. $5^{\circ}$, LIV) e do contraditório e da ampla defesa (CF, art. $5^{\circ}$, LV), acreditamos que ao aludido princípio da presunção de inocência não se pode dar interpretação ampliativa capaz de abranger toda e qualquer situação restritiva de direitos decorrente de ato jurisdicional. Seu âmbito de aplicação deve ser circunscrito exclusivamente ao processo penal, como, aliás, resulta diretamente da interpretação literal do dispositivo constitucional que o agasalha (p. 3-4).

Ora, há muitos meios de evitar que um candidato que cometeu atos ilícitos não se converta em representante político. Não é preciso instituir, em lei, uma restrição generalizante, que atinja o núcleo essencial de uma liberdade geral de ação política, como é o direito político personalíssimo de um cidadão entrar no sistema de disputa eleitoral.

O Supremo Tribunal Federal, em duas importantes decisões, firmou precedentes suficientemente claros para estabelecer uma interpretação ampla e diametralmente oposta à do Deputado José Eduardo Cardozo, em relação ao inciso LVII, do Art. $5^{\circ}$. da Constituição Federal. São precedentes que revelam, para além de toda dúvida razoável, que já foi ultrapassada, pela jurisdição constitucional brasileira, a interpretação restritiva do sentido e do alcance da garantia do princípio da presunção de não culpabilidade.

O primeiro julgamento, histórico porque é apontado como um dos primeiros a aplicar o princípio da proporcionalidade na interpretação constitucional brasileira ocorreu no HC 45.232, em 21/2/1968, em que o Tribunal, reunido em sessão plenária, por maioria, confirmou o relatório do Ministro Themístocles B. Cavalcanti, declarando a inconstitucionalidade da Lei de Segurança Nacional, no tópico em que instituiu a pena de suspensão do direito ao exercício profissional por aqueles acusados de prática de crime de segurança nacional. O destaque vai para o fato de o princípio da não culpabilidade, na época, não ser princípio expresso no texto constitucional. Mas isso não representou um óbice para sua aplicação ao caso.

Se o problema da inconstitucionalidade tivesse de se apoiar numa técnica rígida e puramente legal, certamente Marshall não teria proferido a sua famosa decisão que constitui a base de uma doutrina sobre inconstitucionalidade, já hoje secular. (Voto do Relator, p. 806)

E o Ministro Evandro Lins e Silva asseverou que:

A lei não pode criar uma forma de punição preventiva, sem ferir princípios gerais, o sistema de garantias e dos direitos consagrados pela Constituição (Voto do Min. Evandro Lins e Silva, p. 825)

O segundo julgamento se deu no RE 482.006-4, em 07.11.2007, que teve como relator o Ministro Ricardo Levandowski, no qual a Corte, em sessão plenária, e por unanimidade, entendeu que a redução de vencimentos de servidores públicos processados criminalmente, ainda que em nome da 
preservação da moralidade administrativa, porém não condenados com trânsito em julgado, é prática sancionatória que colide com o disposto no inciso LVII, do Art. $5^{\circ}$ da Constituição Federal.

Nessa decisão, que não recepcionou a Lei 2.364/61, do Estado de Minas Gerais, a Corte fez questão de ressaltar a importância do julgamento,

[O] Tribunal de modo expresso está reconhecendo que o artigo $5^{\circ}$., inciso LVII, da Constituição, é garantia contra a aplicação de qualquer medida gravosa àquele que, como réu, está sendo, ainda, objeto de ação penal, cuja sentença condenatória não transitou em julgado. O Tribunal está reconhecendo que não lhe pode ser aplicada sequer medida de caráter patrimonial; que a garantia constitucional não permite sequer imposição de caráter patrimonial, que é importantíssimo para se fixar o entendimento de que a injunção de gravame de caráter penal, que diga diretamente com restrição à liberdade do réu, a fortiori, não pode ser tolerada perante aquela cláusula constitucional" (RE 482.006-4. Voto Min. Cezar Peluso, p. 486.)

No mesmo caso, assim se manifestou o Ministro Celso de Mello:

Ressalto, como aqui já foi afirmado, a importância deste julgamento, em que o STF, interpretando a Constituição da República, deixa perfeitamente claro que o princípio da não culpabilidade projeta-se além de uma dimensão estritamente penal, alcançando quaisquer medidas restritivas de direitos, independentemente de seu conteúdo, ainda que em sede administrativa." (RE 482.006-MG, DJU de 14.12.2007. Voto do Min. Celso de Mello. Relator)

\section{CONSIDERAÇÕES FINAIS}

É hora de concluir. O inciso LVII, do art. $5^{\circ}$, da Constituição Federal, por tudo o que se viu, consagra o princípio da presunção de não culpabilidade em sentido amplo, isto é, traduz-se em proteção rígida contra a privação da liberdade, de direitos ou de bens; é um inciso que tem sua rigidez assegurada pela exigência de trânsito em julgado e nisso é em tudo coerente com as premissas do constitucionalismo atual. Por ser um princípio fundamental do sistema de garantias constitucionais, sua interpretação deve ser ampliada sempre mais, exatamente como se devem interpretar todas as garantias a direitos fundamentais. Visto que é um princípio garantidor do núcleo essencial das liberdades políticas gerais (positivas ou negativas), é inafastável a sua aplicação aos cidadãos que apresentam seu nome para disputar eleições em busca de capacidade eleitoral passiva.

Não importa em qual campo do direito,

O Estado - que não tem o direito de tratar suspeitos, indiciados ou réus como se culpados fossem (RTJ 176/805-806) - também não pode constrangê-los a produzir provas contra si próprios. (RTJ 141/512); (HC 96.219-MC/SP, Rel. Min. CELSO DE MELLO, v.g.); Precedentes. 
A colisão entre princípios constitucionais se resolve, exclusivamente, pelo procedimento da ponderação. E a ponderação é técnica que reclama argumentação exaustiva, especialmente quando o conflito envolve princípio constitucional de primeiro grau (ALEXY, 2008, 138), como é o caso do princípio da presunção de não culpabilidade. A colisão entre princípios não deve ser resolvida pela anulação de uma liberdade cívica geral em favor de um princípio de natureza administrativa, como a moralidade administrativa. Esse conflito tem um caráter simbólico mais importante do que se pode presumir, à primeira vista. Subjaz a ele o histórico embate ideológico entre as visões estatistas e administrativistas do direito constitucional moderno e as visões humanistas e democráticas do direito constitucional atual.

O constitucionalismo brasileiro, pós-1988, não é do tipo que autoriza a tutela moral dos cidadãos. Bem ao contrário, é do tipo que maximiza a proteção das liberdades individuais e cívicas. O direito constitucional atual, por sua vez, é garantia de liberdades, igualdade e solidariedade. Essa função garantista dos direitos fundamentais não pode ser diminuída em nome de uma prevenção preconceituosa contra indivíduos de conduta duvidosa, como sugeriu o deputado relator do projeto ficha limpa, ou para salvar a política dos políticos, como sugeriu o ex-presidente do TSE e ministro do STF. A interpretação garantista do direito constitucional também não pode ser diminuída por interpretações ligeiras de princípios densos, como o da presunção da não culpabilidade e da irretroatividade das sanções jurídicas, nem com tergiversações em torno da literalidade do princípio da anualidade eleitoral, como tem feito o Tribunal Superior Eleitoral, em evidente desdém ao princípio da fundamentação racional de seus julgados.

\section{REFERÊNCIAS}

ALEXY, Robert. Teoria dos Direitos Fundamentais. Tradução de Virgílio Afonso da Silva. São Paulo: Malheiros, 2008.

BARBOSA, Rui. Obras Completas. V. 42, t. 2, Rio de Janeiro: Senado Federal, 1915.

BATIA, Giovanna; PIZZO, Alessandro. La tutela dell'imputato. Saggio storico concettuale, Diritto \& diritti. Electronic Law Review, Ragusa, n. 13. out. 2005.

BEDAQUE, José Roberto dos Santos. Efetividade do Processo e Técnica Processual. São Paulo: Malheiros Editores, 2006.

BELLO, Enzo. Neoconstitucionalismos, democracia deliberativa e a atuação do STF. (Org.) In: Perspectivas da Teoria Constitucional Contemporânea, Rio de Janeiro: Lumen Juris, 2007.

CADEMARTORI, Sérgio Urquhart de; STRAPAZZON, Carlos Luiz. PRINCIPIA IURIS: uma teoria normativa do direito e da democracia. Pensar: Revista de Ciência Jurídica da Universidade de Fortaleza, Unifor, v. 15.1, 2010.

CADERMATORI, Sérgio Urquhart de; XAVIER, Marcelo Coral. Apontamentos iniciais acerca do garantismo. Nova criminologia. Artigo 45, 2006. Disponível em: www.novacriminologia.com.br/Artigos. 
COSTA, Adriano Soares da. Instituições de Direito Eleitoral. 8. ed. Rio de Janeiro: Lumen Juris, 2009.

Moralismo eleitoral, inelegibilidade e vida pregressa. Disponível em: http://adrianosoaresdacosta.blogspot.com, acesso em: 1 de março de 2010.

DAHL, Robert. Poliarquia: participação e oposição. Tradução de Celso Mauro Paciornik. São Paulo: EdUSP, 1997.

DINAMARCO, Cândido Rangel. A Instrumentalidade do Processo. São Paulo: Malheiros, 2002.

FERRAJOLI, Luigi. A Teoria do Garantismo e seus reflexos no Direito e no Processo Penal. Boletim IBCCRIM, São Paulo, Entrevista n. 77, 14, Dez 1997. Entrevista concedida a Fauzi Choukr.

. Derecho y razón: teoria del garantismo penal. Trad. Perfecto Andrés Ibánez; Alfonso Rui Miguel; Juan Carlos Bayón Mohino; Juan Terradilos Basoco; Rocío Cantarero Bandrés. 6.ed. Madrid: Trotta, 2006.

. Principia luris. Teoria do direito e da democracia. Bari (Italia): Laterza, 2007.

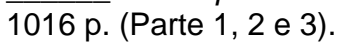

QUINTARD-MORENAS, François. The presumption of innocence in the french and anglo-american legal traditions. The American Journal of Comparative Law. v. 58, p. 107-150, 2010.

LAZERGES C., La présomption d'innocence en Europe, Archives de politique criminelle, 2004/1, v. 26, p. 125-138.

LIMONGI, Fernando; CORTEZ, Rafael. As eleições de 2010 e o quadro partidário. Novos Estudos (CEBRAP), n. 88 (nov 2010): 36, p. 21-37.

MARINONI, Luiz Guilherme. O direito à efetividade da tutela jurisdicional na perspectiva da teoria dos direitos fundamentais. Genesis - Revista de Direito Processual Civil, v. 28. Abr-Jun 2003.

MARTEL, Letícia. Estudos Contemporâneos de Direitos Fundamentais. Rio de Janeiro: Lumen Juris, 2009.

ROCHA, Cármen Lúcia Antunes. República e Federação no Brasil. Belo Horizonte: Del Rey, 1997.

ROMBOLI, R., La tutela dei diritti fondamentali davanti alle Corti Costituzionali, Torino, 1994.

STRAPAZZON, Carlos Luiz. Tratados internacionais, direitos fundamentais e liberdade individual: rupturas e evoluções em 60 anos de jurisprudência do Supremo Tribunal Federal. In. MARTEL, Letícia de Campos Velho (Org.). Estudos contemporâneos de Direitos Fundamentais. Rio de Janeiro/Criciúma: Lumen Juris/UNESC, 2009.

Presunção de não culpabilidade em matéria político-eleitoral: evolução jurisprudencial do STF e valores constitucionais atuais. Revista Brasileira de Direito Eleitoral. , v.2, p.1 - 26, 2010.

VALLINDER, T.; TATE, C. Neal. The global expansion of judicial power: the judicialization of politics. New York: New York University. 1995.

ZAGREBELSKY, Gustavo. Ronald Dworkin's principle based constitutionalism: na italian point of view. International Journal Of Constitutional Law, Oxford, v. 1, n. 4, p. 621-650, abr. 2003.

. Historia y Constitución. Tradução de Miguel Carbonell. Madrid: Trotta, 2005.

Direitos FundamentaIS E JUSTIÇA N 14 - JAN./MAR. 2011 